\title{
Three dimensional analysis of the accumulation rate in the Yahagi delta central Japan
}

\author{
Tomoyuki Sato* and Fujio Masuda**
}

The historical change of accumulation rate of the Yahagi delta are estimated from high resolution carbon fourteen dating from four borehole cores and subsurface map. At result, accumulation volume rate increased abruptly from $5.8 \times 10^{4}$ to $11.1 \times 10^{4}\left[\mathrm{~m}^{3} / \mathrm{y}\right]$ during $5 \sim 2 \mathrm{kyBP}$ although progradation rate decreased gradually from 5.1 to $2.4[\mathrm{~m} / \mathrm{ky}]$. Therefore sediment discharge of the Yahagi river increased abruptly during $5 \sim 2$ kyBP.

Key word : $\mathrm{C}^{14}$ dating, delta, sediment flux, Quaternary

\section{Introduction}

To predict deltas future response to sea-level changes, it is important to understand how delta evolution was affected by past sea-level changes. The sediment discharge is also important factor to delta evolution (Coleman, 1981). Human activities for example cultivation and deforestation affected sediment discharge for the last 2000 to 3000 years (Milliman and Syvitski, 1992). Human effects in sediment discharge were found in Asian large deltas such as Changjiang delta (Hori et al., 2001 ; Chen, 1998), Huanghe delta (Saito et al., 2001 ; Xue, 1993 ; Li, 1991 ; Zhang, 1984) and not found in Mekong delta (Ta et al., 2002).

The purposes of this study are to reveal the history of evolution and sediment discharge of the Yahagi delta in millennium order. History of evolution was reconstructed from facies analysis and high resolution ${ }^{14} \mathrm{C}$ dating. Progradation rates and accumulation volume rates were estimated from bathymetry and ${ }^{14} \mathrm{C}$ dating.

\section{Study area}

The Yahagi delta (Okazaki plain) is located at the mouth of the Yahagi River facing Mikawa bay, central Japan. The Yahagi River is $117 \mathrm{~km}$ long, and drains an area of

Received October 31, 2006 ; Accepted December 20, 2006

* Department of Geology and Mineralogy Graduate School of Science Kyoto University, Kyoto 606-8502, Japan

** Department of Environmental Systems Science, Faculty of Engineering, Doshisha University, Kyoto 610-0321, Japan
$1830 \mathrm{~km}^{2}$. Its water discharge is averaged $53 \mathrm{~m}^{3} / \mathrm{sec}, 2740$ $\mathrm{m}^{3} / \mathrm{sec}$ at most, and $5 \mathrm{~m}^{3} / \mathrm{sec}$ at least. The Yahagi River was changed its lower channel in 1605 , the river was emptying into the central part of the bay though now the river is emptying into the western part of the bay. The channel style is braided. The geology of the drainage area is almost Ryoke granite (Kobayashi, 1972).

The geometry and subsurface structure of the Yahagi delta were revealed by Moriyama and Ozawa (1972) and Kuwahara (1982). Width of delta is about $8 \mathrm{~km}$ at the coast line and decreases gradually to upper stream ward.

\section{Materials and methods}

Four borehole cores were taken from the present delta plain : YG1 $\left(34^{\circ} 47^{\prime} 18.59^{\prime \prime} \mathrm{N}, 137^{\circ} 3^{\prime} 54.08^{\prime \prime} \mathrm{E}\right.$, altitude -0.24 $\mathrm{m}$ above present mean sea level, depth $40 \mathrm{~m})$; YG2 $\left(34^{\circ}\right.$ $50^{\prime} 2.20^{\prime \prime} \mathrm{N}, 137^{\circ} 3^{\prime} 23.68^{\prime \prime} \mathrm{E}$, altitude $+2.58 \mathrm{~m}$, depth $34 \mathrm{~m}$ ); YG3 $\left(34^{\circ} 52^{\prime} 5.22^{\prime \prime} \mathrm{N}, 137^{\circ} 5^{\prime} 31.18^{\prime \prime} \mathrm{E}\right.$, altitude $+5.22 \mathrm{~m}$, depth $23 \mathrm{~m})$; YG4 $\left(34^{\circ} 53^{\prime} 38.80^{\prime \prime} \mathrm{N}, 137^{\circ} 8^{\prime} 14.01^{\prime \prime} \mathrm{E}\right.$, altitude $+9.18 \mathrm{~m}$, depth $21 \mathrm{~m}$ ). Diameter of borehole cores is $65 \mathrm{~mm}$. Core recovery was more than $95 \%$. Four borehole points are located in the incised valley axis every 5 $\mathrm{km}$.

The core samples were split, described, and photographed. Thirty-nine ${ }^{14} \mathrm{C}$ ages were determined by the AMS (accelerator mass spectrometry) method from samples of fossil shells and plants fragments. All ages were calibrated by CALIB 4.4.2 (Stuiver and Reimer, 1993). 


\section{Sedimentary facies}

Seven sedimentary facies were recognized in borehole sediments based on the combined characteristics of lithology, grain size and sedimentary structure. Seven sedimentary facies identified are facies BG, facies LS, facies LA, facies MC, facies UA, facies US and facies TA in ascending order (Fig.1).

\section{Facies BG (Basal Gravel)}

Depth YG1 : 40.0 39.9 m, YG2; 34.0 32.6 m, YG3 : $23.0 \sim 22.0 \mathrm{~m}, \mathrm{YG} 4: 21.0 \sim 20.0 \mathrm{~m}$

Out sized cobbles characterize this facies. Matrix of this gravel is massive very coarse sand and granule. The sedimentary environment is fluvial.

\section{Facies LS (Lower Sand)}

Depth YG1 : 39.9 27.5 m, YG2 : 32.6 21.9 m, YG3 : $22.0 \sim 18.6 \mathrm{~m}$, YG4 $: 20.0 \sim 18.0 \mathrm{~m}$

Coarse sand characterizes this facies. Coarse sands are massive but rarely have trough cross-laminations. Thick- ness of coarse sand is up to $10 \mathrm{~m}$. Mud layers with rootlets insert in this sand. Contacts of coarse sands and mud layers are emotionally. Thickness of mud layers is up to $20 \mathrm{~cm}$. The sedimentary environment is fluvial.

\section{Facies LA (Lower Alternation)}

Depth YG1 : 27.5 19.1 m, YG2 : 21.9 19.5 m, YG3 : $18.6 \sim 9.8 \mathrm{~m}, \mathrm{YG} 4: 18.0 \sim 12.1 \mathrm{~m}$

Upward fining sand-mud alternation and bioturbation characterize this facies. Grain size is silt to fine sand. Scale of each bed is centimeter. Sand beds have parallel or wave ripples laminations. Plant fragments occur in lower to middle part. Shell fragments occur in middle to upper part. The sedimentary environment is estuary.

\section{Facies MC (Middle Clay)}

Depth YG1 : 19.1 8.2 m, YG2 : 19.5 12.2 m, YG3 : none, YG4 : none

Well-sorted massive clay characterize this facies. Many shell fragments occur in this facies. The sedimentary environment is offshore.

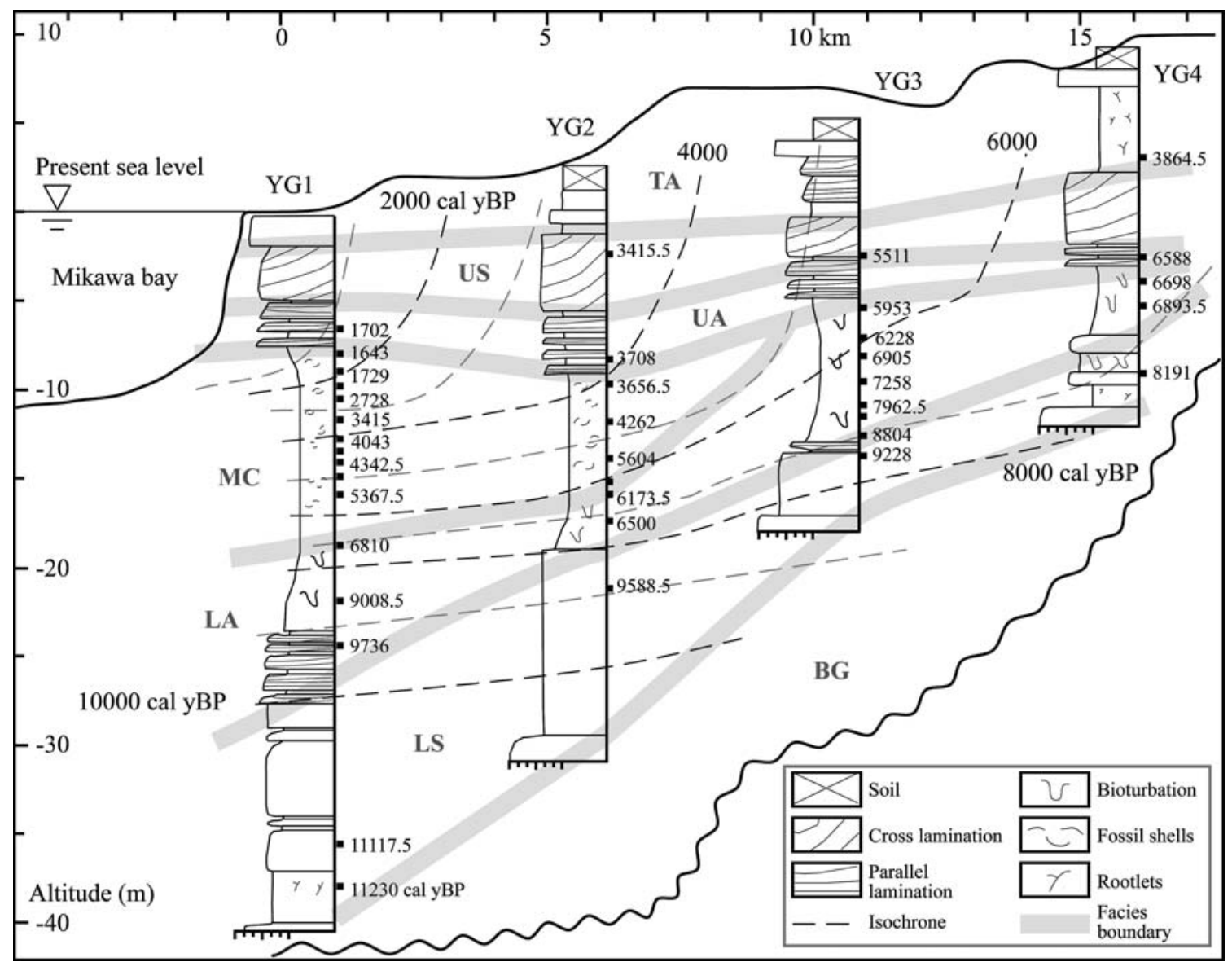

Fig. 1 Cross section and inferred sedimentary facies with isochrones. 


\section{Facies UA (Upper Alternation)}

Depth YG1 : 8.2 5.0 m, YG2 : 12.2 8.2 m, YG3 : 9.8

$\sim 7.7 \mathrm{~m}, \mathrm{YG} 4: 12.1 \sim 11.0 \mathrm{~m}$

Upward thickening sand-mud alternation characterize this facies. Scale of alternation is $2 \sim 30 \mathrm{~cm}$. Alternations have parallel or wave ripple lamination in lower part and cross-lamination in upper part. Many plant fragments occur in mud layers. The sedimentary environment is delta bottom set.

\section{Facies US (Upper Sand)}

Depth YG1 : 5.0 2.0 m, YG2 : 8.2 4.0 m, YG3 : 7.7 $\sim 5.6 \mathrm{~m}, \mathrm{YG} 4: 11.0 \sim 7.1 \mathrm{~m}$

Cross laminated medium sand characterize this facies. Grain size fluctuates vertically from fine to coarse sand. The sedimentary environment is delta foreset.

\section{Facies TA (Top Alternation)}

Depth YG1 : $2.0 \sim 0.3 \mathrm{~m}, \mathrm{YG} 2: 4.0 \sim 1.5 \mathrm{~m}, \mathrm{YG} 3: 5.6$ $\sim 1.2 \mathrm{~m}, \mathrm{YG} 4: 7.1 \sim 1.2 \mathrm{~m}$

Coarse sand and mud with rootlet characterize this facies. Thickness of sand part or mud part is more than $50 \mathrm{~cm}$. Many plant fragments and rootlets occur in both sand and mud parts. Plant fragments occur in this facies. Sedimentary environment is fluvial.

\section{Depositional history}

Depositional history since $10 \mathrm{kyBP}$ was reconstructed based on facies distributional map and isochrones drawn based on thirty-nine ${ }^{14} \mathrm{C}$ ages (Fig. 1).

During transgressive stage (10 7 kyBP), fluvial and estuary deposits infilled incised valley to $-18 \mathrm{~m}$ in the present altitude. Estuary was formed in this area in $9 \mathrm{kyBP}$. Onlap points migrated upper stream ward gradually were at the present coastline to $14 \mathrm{~km}$ in $10 \mathrm{kyBP}$ and to $21 \mathrm{~km}$ in $7 \mathrm{kyBP}$. During progradation stage $(7 \mathrm{kyBP} \sim)$, delta was progradating from upper stream ward. Paleo-coast line was at the present coastline to $15 \mathrm{~km}$ in $6 \mathrm{kyBP}$ and 2 $\mathrm{km}$ in $1 \mathrm{kyBP}$. Estuary environment changed to offshore environment. Marine clay deposited in prodelta. The upper most part was covered by fluvial deposits.

\section{Historical change of the accumulation rate}

Progradation rates and accumulation volume rates were calculated based on distal margins of paleo-delta foresets in each date (Fig. 2). The shapes were drawn to resemble to the present shape. Area of delta were measured based on the area enclosed by two adjacent margins of paleodelta foreset and $0 \mathrm{~m}$ contour of basement (Moriyama and Ozawa, 1972)

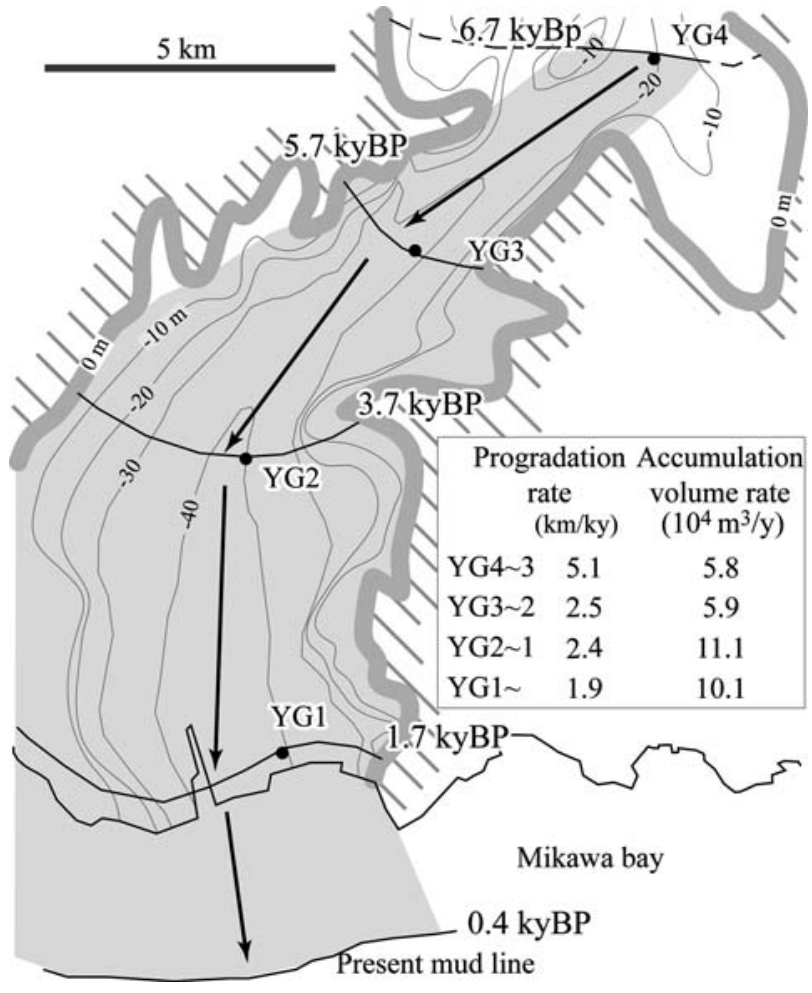

Fig. 2 Basement contour lines (Moriyama and Ozawa, 1972) and Paleo-offshore break of the delta front in 6.7 kyBP, $5.7 \mathrm{kyBP}, 3.7 \mathrm{kyBP}, 1.7 \mathrm{kyBP}$ and present (AD. 1605). Accumulated area is presented by shaded area. Progradation rates and accumulation volume rates are summarized in table.

Progradation rates were decreasing gradually. The rates are $5.1 \mathrm{~km} / \mathrm{ky}$ during $6.7 \sim 5.7 \mathrm{kyBP}$ and $1.9 \mathrm{~km} / \mathrm{ky}$ since $1.7 \mathrm{kyBP}$. On the other hand, accumulation volume rates increased abruptly. The rates are $5.8 \sim 5.9$ before 5.7 1.7 kyBP and 10.1 11.1 after 5.7 1.7 kyBP. According to results, sediment discharge of the Yahagi River increased twice during 5.7 1.7 kyBP.

Sediment-discharge changes in the other Asian rivers are resembled. In Huanghe delta, sediment discharge increased abruptly after 1 kyBP (Zhang, 1984 ; Li, 1991 ; Xue, 1993). In Changjiang delta, sediment discharge increased abruptly after $2 \mathrm{kyBP}$ (Chen, 1998 ; Hori et al., 2001). The cause of abruptly changes is the human activities for example cultivation and deforestation in both deltas (Saito et al., 2001). In the Yahagi delta, many archaeological ruins during $2.4 \sim 1.3 \mathrm{kyBP}$ are discovered (Aichi Prefectural Board of Education, 1988). Human activities therefore are important factor in this area. 


\section{Conclusion}

Depositional history and accumulation rate change in the Yahagi delta were revealed based on four radiocarbondated boring.

Accumulation rate of the Yahagi delta increased abruptly about $3.7 \mathrm{kyBP}$. Human activities are important cause. On the other hand, progradation rate was decreasing gradually.

\section{References}

Aichi Prefectural Board of Education, 1988 : Remains distribution map (2).

Chen, X., 1998 : Changjiang (Yangtze) River delta, China. Joural of Coastal Research, 14, 838-858.

Coloman, J.M., 1981 : Deltas : Processes of Deposition and Models for Exploration. Burgess Pubulishing, Minneapolis, $124 \mathrm{p}$.

Hori, K., Saito, Y., Zhao, Q., Cheng, X., Wang, P., Sato, Y. and Li, C., 2001 : Sedimentary facies and Holocene progradation rates of the Changjiang (Yangtze) delta, China. Geomorphology, 41, 233-248.

Kobayashi, I., 1972 : Geological Map of Japan 1 : 2000000 , Toyohashi. Geological Survey of Japan (in Japanese with English abstract).

Kuwahara, T., 1982 : Subsurface geology and land subsidence in Western Mikawa area. Report about the actual condition and the measure of land subsidence, 8, 96-136 (in Japanese).

Li, Y., 1991 : Changes of the ababdoned Huanghe delta. Geographical Research, 10, 29-38.

Milliman, J.D. and Syvitski, J.P.M., 1992 : Geomorphic/tectonic control of sediment discharge to the oceans : the importance of small mountain rivers. Journal of Geoology, 91, 1-21.

Moriyama, A. and Ozawa, M., 1972 : Geomorphology and Subsurface Geology of the Alluvial Plain of the lower Yahagi River, Central Japan. The Quaterary Research, 11 (4) 193-207 (in Japanese with English Abstract).

Saito, Y., Zuosheng, Y. and Hori, K., 2001 : The Huanghe (Yellow River) and Changjiang (Yangtze River) deltas ; a review on their characteristics, evolution and sediment discharge during Holocene. Geomorphology, 41, 219231.

Stuiver, M. and Reimer, P.J., 1993 : Extended ${ }^{14} \mathrm{C}$ data base and revised CALIB $3.0{ }^{14} \mathrm{C}$ Age Calibration Program. Radiocarbon, 35 (1) 215-230.

Ta, T.K.O., Nguyen, V.L., Tateishi, M., Kobayashi, I., Tanabe, S. and Saito, Y., 2002 : Holocene delta evolution and sediment discharge of the Mekong River, southern Vietnam. Quaternary Science Review, 21, 1807-1819.

Xue, C., 1993 : Historical changes in the Yellow River delta, China. Marine Geology, 113, 321-329.

Zhang, R., 1984 : Land-forming history of the Huanghe river delta and coastal plain of North Jiangsu. Acta Geographica Sinica, 39, 173-184

\title{
3 次元解析による堆積速度の推定 : 中部日本矢作デルタの例
}

\author{
佐藤 智之 - 増田 富士雄, 2007, 堆積学研究, No. 64, 5-8
}

Sato, T. and Masuda, F. : Three dimensional analysis of the accumulation rate in the Yahagi delta central Japan

Jour. Sed. Soc. Japan, No. 64, 5-8

\footnotetext{
愛知県岡崎市周辺の完新統矢作デルタ (岡崎平野) の堆積速度を 4 本のボーリングコア試料を用 いて推定した。堆積相解析によりプロデルタの泥とデルタフロントの砂の境界を求め, その層準 $の^{14} \mathrm{C}$ 年代值を各ボーリングコアで求めることで, デル夕の前進速度を求めた. また, 地下岩層分布 忷と合わせてデルタフロントの砂の体積を見積もり，その堆積速度も求めた。 その結果，砂の堆積 速度が，5〜2 kyBP の時期に $5.8 \times 10^{4}\left[\mathrm{~m}^{3} / \mathrm{y}\right]$ から $11.1 \times 10^{4}\left[\mathrm{~m}^{3} / \mathrm{y}\right]$ へと急増していることがわかっ た. 矢作デル夕の砂の堆積速度は矢作川の堆積物供給量を反映しているであろうから, 矢作川の堆 積物供給量も 5〜2 kyBP の時期以降に急増していることを示唆する.
} 